\title{
Popular Medicine
}

In 1602, Frances Herring, Fellow of the prestigious London College of Physicians, remonstrated:

If a man have a scruple in Conscience, hee will not repaire unto an Hedge Priest ... for resolution, but to some Learned, godly, and Judiciall divine. If a suit in Lawe, he will not resort to a Husbandman or Artificer, for Counsell and Direction, but to a skilful, wellstudyed and approved Lawyer: And yet (such is the extreme folly and madnesse of many Men), that in case of Health and Life (things most pretious) they think every Tinker, Bankerupt, or wandering fugitive, who has over-runne his creditors, forsaken his Trade, and seeketh to live (like a Droan without any Calling) a sufficient and compleat Physition, to advise, counsel, and direct them. ${ }^{1}$

Employing a lexicon of pronounced binaries, Herring's tract evokes a picture of the early modern medical marketplace in which the services of the professional, University-educated, 'compleat' and 'True Physition' were continuously passed over in favour of 'Counterfeit Mountebanks': a motley line up of dubious types including criminals, debtors, the unemployed and - according to his tract's suggestive title - exotic foreigners (hence 'Orient Colours'). By the early seventeenth century such complaints were familiar: in 1566 the eminent physician John Securis railed in print against the "unlearned surgeons, meddling empirics, and "presumptuous" women' who offended his sense of proper medical order and in 1565 the surgeon John Hall lamented the way 'true' practitioners had to compete against 'smiths, cutlers, carters ... and a great rabble of women'. ${ }^{2}$ Dedicating his tract to the Lord Chief Justice, Sir John Popham, Herring was ostensibly seeking judicial help to save sick people from their own 'folly and madnesse' by restricting medical practice to professionals; in reality, as revisionist historiography has compellingly argued, Herring and his colleagues in the College of Physicians and Barber Surgeon's Hall were waging war against unlicensed practitioners, with the aim of increasing their share of a lucrative commercial sphere. ${ }^{3}$ It was a tough challenge; recent scholarship has revealed

\footnotetext{
${ }^{1}$ Frances Herring, Anatomyse of the True Physition, and the Counterfeit Mountebank, Wherein both of them, are graphically described and set out in the Right and Orient Colours (London, 1602), sig. A3r. ${ }^{2}$ John Securis, $A$ Detection and Querimonie of the Daily Enormities and Abuses Committed in Physic (London, 1566), and John Hall, A Most Excellent and Learned Woorke of Chirurgerie (London, 1565), sig. 3r-v.; both cited in Deborah E. Harkness, 'A View from the Streets: Women and Medical Work in Elizabethan London', Bulletin of Medical History, 82/1 (2008): 52-85, 53-4.

${ }^{3}$ See Harkness, 'A View From the Streets', 52-85, and Mary Elizabeth Fissell, 'Introduction: Women, Health, and Healing in Early Modern Europe', 1-17; both part of the important collection of essays in Bulletin of Medical History, 82/1 (2008). See also, Charles Webster, 'William Harvey and the Crisis of Medicine', in Jerome J. Bylebyl (ed.), William Harvey and His Age
} 
that licensed physicians, surgeons and apothecaries were, indeed, probably vastly outnumbered by a wide range of other health care workers. In an important study of community health work in London between 1560 and 1610, Deborah Harkness has identified just over 1400 men and women who did medical work 'including apothecaries, midwives, carers for the sick in hospitals and private settings, surgeons and physicians'. She calculates that $70 \%$ of these were unlicensed, and approximately $30 \%$ of the unlicensed practitioners were women. ${ }^{4}$

The activities of that $70 \%$ are the central concern of this chapter on popular medicine which seeks to achieve two ends: first, to look beyond the hostile rhetoric and professional jealousies of medical men such as Herring, Securis and Hall - those who inhabited the privileged spaces of the College of Physicians and Barber Surgeons Hall - and to peer instead into the homes, streets, and marketplaces of London and beyond, in order to gain a more balanced picture of the most prevalent medical providers and their practices. Who were these intriguing 'presumptuous women', 'meddling empirics', 'mountebanks' and 'orient' types and what were they selling? Secondly, by surveying the range and matter of the commonest medical publications, this study aims to uncover the most popular sixteenth- and seventeenth-century beliefs — 'those with the greatest cultural permeation or purchase' - about the body, its illnesses and cures. ${ }^{5}$

\section{Medical Choices}

We begin in the home of the Reverend Ralph Josselin: where did this man of the 'middling sort' turn when his family and servants were unwell? Strikingly, as Mary Lindemann describes, Josselin's journal records illness 762 times but he only mentions seeking help from outside the family circle on 21 occasions. ${ }^{6}$ Margaret Pelling has demonstrated how at times of illness the first place people turned to was the household where women's presence, knowledge and skills were

(Baltimore: John Hopkins, 1978), pp. 1-28; Andrew Wear, Knowledge and Practice in English Medicine, 1550-1680 (Cambridge: Cambridge University Press, 2000), p. 58.

${ }^{4}$ Harkness, 'A View from the Streets', 58. See also, Margaret Pelling, The Common Lot: Sickness, Medical Occupations and the Urban Poor in Early Modern England (Longman: London, 1998); Mary Fissell, Patients, Power and the Poor in Eighteenth-Century Bristol (Cambridge: Cambridge University Press, 1991).

${ }^{5}$ See Sue Wiseman, “Popular Culture”: A Category for Analysis?” in Matthew Dimmock and Andrew Hadfield (eds.), Literature and Popular Culture in Early Modern England (Farnham: Ashgate, 2009), p. 21.

${ }^{6}$ The Diary of Ralph Josselin, 1616-1683, cited in Mary Lindemann, Medicine and Society in Early Modern Europe (Cambridge: Cambridge University Press, 2010), pp. 246-7; see also Alan Macfarlane, The Family Life of Ralph Josselin, a Seventeenth-Century Clergyman: An Essay in Historical Anthropology (Cambridge: Cambridge University Press, 1970). 
focussed. ${ }^{7}$ As for the majority of early modern families, then, diagnosis and treatment took place in Josselin's home with his wife, Jane, providing the necessary medicines and nursing care. She concocted common herbal remedies such as hyssop syrup herself and occasionally bought preparations from an apothecary or purchased brand-label medicines such as Tabor's Pills and Daffy's Elixir. Ralph and Jane sometimes sought advice from neighbours, from a nearby gentlewoman, and assistance from two local female bonesetters. The Josselins called upon a physician on just four occasions: once when a child was dying; once when Ralph suffered a bout of ague; and twice for Ralph in his terminal illness. ${ }^{8}$ Since the primary cause of illness was always God's displeasure, and healing came from him too via His 'instruments', we should not forget that prayers and the avoidance of sin were integral to both prevention of sickness and the recovery of health for a godly family such as Josselin's.

The journal's mention of seeking help from a 'gentlewoman' is interesting: in recent years, much has been uncovered about the extensive medical activities of charitable gentlewomen who might resemble the one consulted by the Josselins.9 As Linda Pollock, Lynette Hunter and Elaine Leong have illuminated, many of these women were renowned for practising fashionable 'kitchin physick', distilling herbal and mineral remedies in large quantities to supply family, friends and the local neighbourhood. ${ }^{10}$ Elizabeth Grey, Countess of Kent, appears, for example, to have built up an impressive recipe collection that was published posthumously in $A$ Choice Manual of Rare and Select secrets in Physick and surgery (1653). ${ }^{11}$ Lady Grace Mildmay was particularly renowned for her knowledge in 'physicke and surgerie'- she had apparently received instruction in this at home - and her journal between 1570 and 1617 suggests she carried out a wide range of medical activities in her neighbourhood as part of her godly, religious duty. ${ }^{12}$

\footnotetext{
${ }^{7}$ Margaret Pelling, 'Thoroughly Resented: Older Women and the Medical Role in Early Modern London', in Lynette Hunter and Sarah Hutton (eds.), Women and Science, 1500-1700: Mothers and Sisters of the Royal Society (Stroud: Sutton Publishing, 1997), pp. 63-88, 70. See also, Lucinda Beier, Sufferers and Healers: the Experience of Illness in Seventeenth-Century England (London: Routledge, 1987). ${ }^{8}$ See Lindemann, Medicine and Society, p. 247.

${ }^{9}$ See, for example, the many excellent essays in Lynette Hunter and Sarah Hutton (eds.), Women, Science and Medicine 1500-1700 (Stroud: Sutton Publishing Ltd., 1997). See also, Wear, Knowledge and Practice, pp. 50-55.

${ }^{10}$ See Elaine Leong, 'Making Medicines in the Early Modern Household', Bulletin of Medical History, 82/1 (2008): 145-68.

${ }^{11}$ See Lynette Hunter, 'Women and Domestic Medicine: Lady Experimenters, 1570-1620', in Hunter and Hutton (eds.), Women Science and Medicine, pp. 89-107; 89-90, 103-4.

${ }^{12}$ Linda Pollock, With Faith and Physic: the Life of a Tudor Gentlewoman Lady Grace Mildmay 15521620 (London: Collins and Brown, 1993), pp. 66, 146; Margaret P. Hannay, " "How I these
} 
To turn now to a less devout household, Samuel Pepys' diary provides a salutary window onto the sorry and painful business of living with chronic illness - in his case kidney stones. The 'magic bullet' cures that we expect from medicine today simply didn't exist-patients were rarely cured and frequently had to manage a life-time of chronic discomfort and disability. Many, too, likely had their suffering increased by iatrogenic illnesses inflicted on them through harmful medical interventions and poisonous drugs. ${ }^{13}$ Pepys' diary entries find him periodically crying, roaring, trembling, and performing all kinds of bodily contortions during his attacks of excruciating pain caused by stones. ${ }^{14} \mathrm{He}$ did, however, endure lesser suffering with considerable fortitude: for example, on the $3^{\text {rd }}$ and $4^{\text {th }}$ of June, 1664, suffering 'constant akeing' in his back, which he had experienced for six days, he criss-crossed London travelling from his home, to his office, to the exchange, to Whitehall, to St James, engaging in a cramped schedule of business meetings and social gatherings. ${ }^{15} \mathrm{He}$ was obsessively anxious about 'catching' cold, or overheating, and actively avoided horseback when his 'old pains' were bad. Understandably, his favourite self-medication seems to have been good, mature wine. He kept his bowels loose by self-dosing with unpleasant preparations like Cassia and Turpentine but he swore by something else too - a 'Hares foot' worn against the body to ward off wind and colic. ${ }^{16}$ Supernatural and other placebo effects and 'doing something' in the face of discomfort should not be dismissedthese were undoubtedly important psychological props. In 1662 he felt 'exceedingly full of blood' and called upon a surgeon to let his blood; he regularly consulted physicians, too, whose prime prescriptions for his condition were 'glisters' (enemas). As a young man, in 1658, Pepys had chosen to have a life-threatening kidney stone surgically removed; he selected a surgeon from St Thomas' and Bart's hospital and he survived this radical and dangerous procedure that was frequently fatal, declaring himself fully recovered after 35 days. ${ }^{17}$ However, it appears that his old wound had never really healed: when he died in 1703 an autopsy revealed that his left kidney

Studies Prize": the Countess of Pembroke and Elizabethan Science', in Hunter and Hutton (eds.), Women, Science and Medicine, pp. 108-121, 110; William Kerwin, “Where Have You Gone, Margaret Kennix?”: Seeking the Tradition of Healing Women in English Renaissance Drama', in Lillian R. Furst (ed.), Women Healers and Physicians: Climbing a Long Hill (Kentucky: University Press of Kentucky, 1997), pp. 93-113, 111, n 10.

${ }^{13}$ Fissell, 'Introduction: Women, Health, and Healing', 14.

${ }^{14}$ See, for example, 11 October 1661, vol. 2, p.194; 2 August 1662, vol. 3, p. 153; 14 May 1664, vol. 5, p. 150 in Robert Latham and William Matthews (eds.), The Diary of Samuel Pepys: a new and complete transcription (10 vols., London: G. Bell and Sons Ltd, 1970-2).

${ }^{15}$ Discussed in Margaret Healy, 'A Most Troublesome and Dangerous Ailment: Encounters with the Stone in Early Modern Europe’, Journal de la Renaissance, 3 (2005): 207-16, 210.

${ }^{16}$ Healy, 'A Most Troublesome and Dangerous Ailment', 214.

${ }^{17}$ See Pepys's biography by Claire Tomalin, Samuel Pepys: the unequalled self (Penguin: Viking, 2002), pp. 61-5. 
was a mass, full of stones, adhering to his back and that his old wound, bladder and gut were all septic. $^{18}$

Against this picture of chronic infection in the lower regions throughout his adult life, it is, perhaps, not surprising that Pepys and his wife were afflicted by infertility. For this, as Mary Lindemann describes, he sought advice from friends and gathered a range of harmless but ineffective suggestions in the form of 'old wives' tales'. These included, not hugging his wife too hard; not eating late; drinking sage juice and herbal ale with sugar; keeping his stomach warm and his back cool; wearing cool Holland-drawers and asking his wife not to go too 'straitlaced'. ${ }^{19}$ When his eyes failed in 1668 he consulted a famous eye specialist who prescribed a laxative and an eye drop. A year later (Spring 1669) the situation was no better and his haberdasher recommended treatment by 'the mistress of the house, an oldish woman in a hat'. The latter bathed and dressed his eyes and made them smart 'most horribly'. His vision worsened and a month later he had to stop writing his journal. ${ }^{20}$

As we have seen, Pepys's sources of advice and medical choices ranged widely, involving self-medication, supernatural, folkloric and dietary measures, surgical procedures, apothecary's drugs, professional physic, treatment from an eye specialist and at least one local healer or cunning woman. Pepys was of the middling sort, but would the choices of an aristocrat in extremis be so wide-ranging, or more confined to expensive, elite practitioners? The case of the thirty-five year old Earl of Derby's final illness in 1594 is fairly well-documented and might provide some insights into this question. As Judith Bonzol describes, when the Fifth Earl's frightening symptoms of vomiting blood, jaundice, weight-loss and distressing hiccups gave rise for concern, his physicians - who lived some distance away - were summoned to his bedside. ${ }^{21}$ However, in the interval before they arrived, the Earl had self-medicated with a 'glister' followed by an oral laxative of rhubarb and manna; he was also consuming rare drugs containing 'Bezar's stone' and 'Unicorn's Horn' (probably ground bone) - thought to be antidotes against poison. Two surgeons were on hand and when he ceased to pass urine they attempted - unsuccessfully to catheterise him and drain his bladder. When the physicians eventually arrived, they found the Earl being treated by a 'homely woman', 'straining herbs in a pot and chanting... blessings' - a

\footnotetext{
${ }^{18}$ Tomalin, Pepys, p. 38.

${ }^{19}$ See Lindemann, Medicine and Society, p. 245.

${ }^{20}$ Lindemann, Medicine and Society, p. 246.

${ }^{21}$ For a detailed account see, Judith Bonzol, 'The Death of the Fifth Earl of Derby: Cunning Folk and Medicine in Early Modern England', Renaissance and Reformation 33/4 (Autumn 2010): 73-100, 77-9.
} 
local cunning-woman. ${ }^{22}$ It would seem, then, that the Earl did employ the services of at least one unlicensed, neighbourhood healer. Cunning-folk, wise women and white-witches, root-wives and herbalists probably existed in every village and were plentiful in towns. They had special knowledge of local plants which could be brewed into herbal remedies or concocted into salves and lotions to be smeared onto bruises, sore gums, blisters and wounds. ${ }^{23}$ As folk healers, some went beyond traditional herbal remedies and employed astrology and/or magic, or religious incantation too.

Early modern drama is revealing of the range of activities and specialist practices popularly associated with such local healers. Thomas Heywood's cunning woman of The Wisewoman of Hogsdon (quarto 1638) maps out London on the basis of her fellow practitioners' specialisms:

You have heard of Mother Nottingham, who for her time, was prettily well skill'd in casting of Waters: and after her, Mother Bombye; and then there is one Hatfield in PepperAlley, hee doth prettie well for a thing that's lost. There's another in Coleharbour, that's skill'd in the Planets. Mother Sturton in Goulden-lane, is for Fore-speaking: Mother Phillips of the Banke-side, for the weaknesse of the backe: and then there's a very reverent Matron on Clarkenwell-Green, good at many things: Mistris Mary on the Banke-side, is for recting a Figure: and one (what doe you call her) in Westminster, that practiseth the Booke and the Key, and the Sive and the Sheares: and all doe well, according to their talent. ${ }^{24}$

Hogsdon's own wise-woman is presented as a cunning entrepreneur who diagnoses diseases by inspecting flasks of urine; additionally, she reads palms, tells fortunes, treats madness, as well as engaging in a range of more questionable practices (3.1.p. 310). She boasts:

Let mee see how many Trades have I to live by: First, I am a Wise-woman, and a Fortune-teller, and under that I deale in Physicke and Fore-speaking, in Palmistry, and recovering of things lost. Next, I undertake to cure Madd folks. Then I keepe Gentlewoman Lodgers, to furnish such Chambers as I let out by the night: Then I am

\footnotetext{
${ }^{22}$ In Bonzol, 'The Death of the Fifth Earl of Derby,' 79.

${ }^{23}$ Lindemann, Medicine and Society, p. 259. See also Owen Davies, Popular Magic: Cunning-Folk in English History (London: New York: Hambledon Continuum, 2007).

${ }^{24}$ Thomas Heywood, The Dramatic Works of Thomas Heywood, ed. R. H. Shepherd (6 vols., 1874; New York: Russell and Russell, 1964), vol. 5, Act 2, scene 1, pp. 292-3. No line numbers given.
} 
provided for bringing young Wenches to bed; and for a need, you see I can play the Match-maker. (3.1.p.310)

The cunning woman of John Lyly's, A Pleasant Conceited Comedie called Mother Bombie (printed, 1594), ${ }^{25}$ is rather more strange and intriguing. 'Fowle' and 'olde' (2.3.1.97, p. 191) - a 'beldam' (3.1.p.195) - she is hailed as a good woman but also as a witch; significantly, she quickly corrects her clientele, insisting that she is not a witch but rather an honest, cunning woman. Among her skills are those of expounding dreams and telling fortunes by reading hands and peering into eyes. There is an oracular, mysterious quality to her riddling pronouncements. Mishap, misconception and mistaken identity are resolved through Mother Bombie's interventions and the community's harmony is engineered by her riddling utterances. Crucially, she doesn't deceive and she doesn't do harm; in fact she is presented as a gifted social healer. ${ }^{26}$

Cunning women's outlandish and superstitious activities could easily be dismissed today as the ineffectual stuff of comedy; however, they do appear to have been key players in the real medical economy and the interventions of such healers probably did no more harm, and potentially just as much good, as those of licensed physicians. Many of their practices (reading flasks of urine, casting horoscopes, interpreting dreams) appear to have overlapped with those of the 'professionals', and there is, after all, little evidence that learned medicine was helpful beyond its placebo effects; its bizarre and intrusive regimes of purging, inducing vomits, sweating and bleeding were painful and dangerous, even causing diseases and death. Indeed, the commercially successful empiric Simon Forman railed against learned physicians virtually accusing them of homicide: 'For they wold mak the pisse \& excrement of the bodi to be greter then the bodie yt cam from....And they thrive therafter for wher they cuer on[e] they hurte 20, and where they helpe on[e] they kill 20,. ${ }^{27}$ Meanwhile, Francis Bacon reflected that 'empirics and old women are more happy many times in their cures than learned physicians, because they are more exact and religious in holding to the composition and confection of tried medicines.' 28 Undoubtedly, folk healing based on tried and tested experience and practised by skilled

${ }^{25}$ John Lyly, The Complete Works of John Lyly, ed. R. Warwick Bond (Oxford: Clarendon Press, 1942).

${ }^{26}$ See William Kerwin, Beyond the Body: The Boundaries of Medicine and English Renaissance Drama (Amherst and Boston: University of Massachusetts Press, 2005), pp. 62-96; and 'Where Have You Gone Margaret Kennix?', pp. 99-101.

${ }^{27}$ Cited in Lauren Kassell, Medicine and Magic in Elizabethan London: Simon Forman, Astrologer, Alchemist, and Physician (Oxford: Clarendon Press, 2005), p. 119

${ }^{28}$ Francis Bacon, De Augmentis Scientiarum (1623), in The Works of Francis Bacon, trans. and eds., James Spedding, Robert Ellis and Douglas Heath (15 vols., London, 1858), vol. 4, p. 388. 
practitioners might well have been a safer choice than consulting an expensive academic physician. This could help to explain why traditional healers like the renowned Margaret Kennix were sometimes protected (not always successfully) from the onslaughts of the College of Physicians by Queen Elizabeth's intervention.

In 1581 Francis Walsingham, the queen's secretary of state, addressed this letter to the college:

Whereas heretofore by her Majesties commandment upon the pitiful complaint of Margaret Kennix I wrote unto Dr. Symondes of your College and fellowship of Phisitions within the City, signifying how that it was her Highness pleasure that the poore woman should be permitted by you quietly to practise and minister to the curing of diseases and woundes, by the means of certain Simples, in the applying wherof it seemeth God hath geven her an especial knowledge, to the benefit of the poorer sort and chiefly for the better maintenance of her impotent husband and charge of Family, who wholy depend on the exercise of her skill: Forasmuch as now I am enformed, she is restrained either by you ...contrary to her Majesties pleasure, to practise any longer said manner of mynistring of Simples....I shall therefore desire you forthwith to take order amongst yourselves for the readmitting of her into the quiet exercise of her small Talent... ${ }^{29}$

Kennix's special 'talent', notably her God-given knowledge of 'simples' and her ability to cure wounds thereby, are reminiscent of another, rather more reputable and authoritative stage healer than the wise-women encountered above: the 'empiric' (unlicensed healer), Helena, in Shakespeare's All's Well that Ends. Her goodness and simplicity are stressed, she works by 'inspired merit' using tried and tested medicinal receipts, and she is successful in curing the king's 'past-cure malady' - his fistula - when the combined efforts of the 'congregated College' of 'learned doctors' have failed $(2.2 .148,114-23) .{ }^{30}$ It is significant that early modern drama often foregrounds the woman healer as socially marginalised yet possessing an oracular nature and heightened spiritual and curative powers. As William Kerwin observes, 'she' (the stage healer) frequently refutes the attacks on women practitioners - she is not malevolent and she is often

${ }^{29}$ Annals of the College of Physicians'. Manuscript, Royal College of Physicians, London, 6; cited in Kerwin, Beyond the Body, p. 81.

${ }^{30}$ William Shakespeare, All's Well That Ends Well, The Complete Works: Compact Edition, eds. Stanley Wells and Gary Taylor (Oxford: Clarendon Press, 1988), Act 2, Scene 2, 1l. 148, 114-23. 
highly skilful. ${ }^{31}$ Such representations are a healthy antidote to the slurs and aspersions cast upon them in the physicians' and surgeons' polemics.

In the early modern period, the relationship between performance and healing was particularly intimate: with a wide range of healing options to choose from, patients would certainly have been inclined to spend their pennies on those practitioners who were most effective at convincing of their authority and the efficacy of their 'cures' and products. Acting a convincing part was also crucial to securing placebo effects-patients had to be persuaded to believe in their healer. While learned physicians harnessed professional mystique by advertising their university credentials, using Latin, strutting about their consulting rooms and environs in special gowns inspecting flasks of urine ritualistically, Europe's army of itinerant practitioners, including mountebanks, charlatans, quacks, tooth-drawers, bone-setters, oculists, and lithotomists, were renowned for their - sometimes very sophisticated - marketplace theatre.

Distinct lines beween mountebanks, charlatans and quacksalvers are difficult to draw, however, M.A.Katritsky suggests that, 'broadly speaking, mountebanks are itinerant performers who sell medical products and services, charlatans are itinerant performers who sell medical products and services, and quacksalvers are sellers of medical products and services who may or may not be itinerant or perform in public, ${ }^{32}$ As Katritsky describes, stage quacks have an interesting history: they first appear in Latin mystery plays preserved in twelfth- and thirteenthcentury manuscripts, emerging occasionally as dominant, 'extremely popular', non-biblical characters in Easter mystery plays. The German religious stage developed particularly extensive quack scenes and, interestingly, in the fifteenth- century Erlau Easter play, Medicus introduces himself as 'a skilled master of noble birth from Asia'. He claims to have brought the troupe's medicines from 'Milan, Flanders and Arabia'. ${ }^{33}$ The association of Medicus and his drugs with exotic locations appears to heighten their desirability and imagined efficacy, increasing the value and earning power of both his services and his wares. We might pause to reflect, here, on Herring's anxiety about 'Orient Colours' expressed in the title of his tract, and the way these are associated with 'counterfeit' physicians: claiming exotic connections seems to have been a regular feature of later mountebank theatre which incorporated foreign rhetoric and costumes with 'a strong Eastern flavour'- a clever ruse designed to heighten takings. ${ }^{34}$ Quack theatre was also one of the earliest venues where the curious might encounter female performers for the first time. As

\footnotetext{
${ }^{31}$ Kerwin, 'Where Have you Gone, Margaret Kennix?, p. 100.

${ }^{32}$ M. A. Katritsky, Women, Medicine and Theatre, 1500-1750: Literary Mountebanks and Performing Quacks (Aldershot: Ashgate, 2007), p. 5.

${ }^{33}$ Katritsky, Women, Medicine, pp. 37, 40.

${ }^{34}$ Katritsky, Women, Medicine, p. 81.
} 
Katritsky foregrounds, in the Erlau play, Medica, the quack's wife, comically interrupts the action, requesting that her medical skills, too, be enumerated; while she apparently offered marriage guidance, counselling and a women's clinic, her husband performed surgery. ${ }^{35}$ That quack and mountebank theatre made people laugh and was often combined with music and dance was important for two reasons: the latter were widely considered to have therapeutic powers and comic engagement attracted larger audiences. Katritsky explains that there were other aspects of mountebank performance which sound compelling and significant:

Central to the theatrical activities of many quacks was a class of performative routines ultimately intended not simply to attract and divert potential customers, or even to showcase the merits of their skills and patent medicines, but as powerful demonstrations, by natural or supernatural means, of the quack's personal authority over death. It encompassed onstage medical procedures, reports of wondrous happenings or other news items, or the staging of dangerous or magical routines ranging from sleight of hand or playing with live snakes to decapitations or even human flight. ${ }^{36}$

It would appear that powerful stage enactments of authority over death (reminiscent of shamanistic activities) could be highly lucrative; medicine and performance were certainly closely intertwined in early modern times.

Margaret Cavendish's Sociable Letters reveal that she was captivated by an Italian Mountebank group during her sojourn in Antwerp, returning every day to watch them perform:

Here coming an Italian Mountebank, who had with him several persons to Dance, and Act upon the open Stage, also one which did Act the part of a Fool, and that all to draw a Company of People together, to hear him tell the Virtues, or rather Lies of his Drugs, Cures, and Skill, and to Intice, or Perswade them to Buy....I saw this Fool Act his part so well, that many of the People bought more Drugs for the Fool's sake, than for the Apocryphal Physician's, which was the Mountebank. ${ }^{37}$

Cavendish was particularly riveted by the troupe's actresses and disappointed when the company disappeared from the city. She speculates:

\footnotetext{
${ }^{35}$ Katritky, Women, Medicine, p. 40.

${ }^{36}$ Katritsky, Women, Medicine, p. 87.

${ }^{37}$ Margaret Cavendish, CCXI Sociable Letters (London: William Wilson, 1664), pp. 405-6.
} 
some said, the Physitians through Envy to the Mountebank, Bribed them out; the truth is, they had Reason, for the Mountebank was then so much in request, as most of the people made him their Doctor, and Jaen Potage (for so the Fool was named) was their Apothecary. ${ }^{38}$

The envious polemic of Dr Frances Herring encountered at the outset of this chapter, suggests that the situation in seventeenth-century London was probably very similar; indeed, Sir Francis Bacon's words confirm that physicians were not a popular medical choice - 'men ... will often preferre a Montabanke or Witch before a learned Phisitian. ${ }^{39}$

\section{The Body in Common}

It would be easy to assume a sharp dichotomy separating the 'true' understanding about the body held by early modern university-trained physicians from the presumed ignorance and erroneous beliefs of unqualified healers and the general populace. In fact until the 1970s, the history of early modern medicine focused, almost exclusively, on the academic men who practised learned medicine and their management of diseases; however, the 70s experienced a surge of interest in recovering and studying alternative forms of healing - 'popular' medicine, as it was labelled at the time. In the first decades of this research, unorthodox, unlicensed, empirics, quacks, mountebanks, cunning folk and white witches sat largely on the superstitious, supernatural, 'low' side of the imagined fence, while educated, licensed practitioners who were assumed to practice a more scientific, secular, therapeutically sound form of physic, occupied the orthodox, 'elite' side of the fence. The divisive, vitriolic attacks against unlicensed practitioners readily accessed in the archives of the Royal College of Physicians and the Barber Surgeons' Hall encouraged historians to think in these terms. However, as Mary Lindemann reflects, there is now widespread agreement among medical historians that rigid binaries were a misrepresentation: 'It became clear that such dichotomies were flawed and that the overlap of 'popular' and 'elite'-or rather the presence of a broad substratum of common beliefs about health, illness, and therapeutics that most members of the society shared-best characterized early modern medicine'. ${ }^{40}$ An

\footnotetext{
${ }^{38}$ Cavendish, Sociable Letters, pp. 407-8.

${ }^{39}$ Francis Bacon, The Two Bookes of Francis Bacon. Of the Proficience and Advancement of Learning, Divine and Humane (London: Henry Tomes, 1605), II, f.3v.

${ }^{40}$ Lindemann, Medicine and Society, pp. 1-17, 16.; Wear, Knowledge and Practice, pp. 28-9; Fissell, Introduction: Women, Health and Healing, 1-17.
} 
examination of the cheaper end of the medical print market will help to illuminate these 'common beliefs'.

The sixteenth century witnessed a vast outpouring of relatively inexpensive quarto publications in the vernacular that might best be described as self-help guides to maintaining the body in health. Sir Thomas Elyot announced that his treatise or medical regimen, The Castel of Helth (London, 1539), dealt with, 'the Conservation of the body of mankynde, within the limitation of helth, which (as Galene sayth) is the state of the body, wherin we be neyther greved with peyne, nor lette from doing our necessary busynesse' (f.1r). His was a ground-breaking and highly influential text, which essentially pedalled the same Galenic, humoral model of the body that was taught in all the universities of early modern Europe. Academic medicine circa 1500 relied solely on book-learning: it was static knowledge gained largely from ancient Greek and Roman texts; there was no experimental element and it was not scientific in the modern sense of the term. The Galenic paradigm basically imagined the body as a large container of seething fluids called humours, which were made from the food and drink people consumed, and which had a nasty habit of increasing to the point of 'repletion' and excess, leading to 'corruption' and subsequent sickness (f.8r). Humoral balance was also affected by changes in the external environment—strong winds and rain, or periods of drought, could, for example, impact on the internal bodily environment. ${ }^{41}$ Air that stank and was 'corrupted' by putrid things like unburied carcasses and stagnant water was thought to produce 'miasmas'- airbourne poisons-which could be breathed in and give rise to diseases such as plague (Elyot, f.12r). ${ }^{42}$ Bodies that were not in humoral homeostasis were prone to contracting such infections. The planets, too, influenced health and sickness; man and the universe were thus closely intertwined. From ancient times, through the early modern period and beyond, this was the dominant medical model of the body and it is probably how most people - lay and learned - imagined themselves. ${ }^{43}$

The literate could refine and extend their knowledge of the humoral body by reading texts such as Elyot's where they would learn that the four humours were blood, phlegm, black bile and yellow bile and these each had 'qualities' of heat/cold and dryness/moisture; the predominance of particular qualities determined one's 'complexion' or personality type. ${ }^{44}$ Elyot's Castel provides a list of characteristics of each complexion. Thus the 'colerike' complexion is 'hote and drie' with a lean and lofty body; black or dark auburn, curly hair; a face as red as fire; a

\footnotetext{
${ }^{41}$ Margaret Healy, Fictions of Disease in Early Modern England: Bodies, Plagues and Politics (Basingstoke: Palgrave, 2001), pp. 18-28; Wear, Knowledge and Practice, pp. 37-40.

${ }^{42}$ Healy, Fictions of Disease, pp. 35-7.

${ }^{43}$ Lindemann, Medicine and Society, p. 17.

${ }^{44}$ Sir Thomas Elyot, The Castel of Helth (London, 1539), f.2r-3r. All citations are to this edition.
} 
high voice; and the 'colerike' temperament is associated with little sleep; dreams about fire, fighting or anger; and a sharp wit (f.2v). In order to maintain health, the individual needed to identify his complexion - choleric, sanguine, melancholy, phlegmatic -from such lists and adjust his 'regimen', or habits and self-government, to suit his particular 'complexion' (f.2r-3r). 'Proper regimen' meant assiduously attending to the six 'non-naturals': namely, air quality; sleep and waking; food and drink; rest and exercise; excretion and retention; and the passions, including sex and the emotions (f.3r). Exercising temperance, with the restraint of all excesses, was the key to maintaining health. If the body became over-full it required some assistance: the diet had to be adjusted and the bodily container could be vented, and balance restored, by enemas, by taking purgatives and emetics, and by blood-letting (usually undertaken by a surgeon or other healer). Such notions about the body and its care were also transmitted orally and were widely accepted; they informed not only medical theories but more popular conceptions of health and illness as well'. ${ }^{45}$ By the early seventeenth century, however, the humoral body had a powerful rival in the form of an alchemical-religious medical model introduced by the Swiss-German physician, Paracelsus, a century earlier. This encouraged a view of the body and the universe (the two were even more closely intertwined in this model), as a vast chemical distillery overseen by God, the divine alchemist. From the mid seventeenth century a more mechanistic body-type - man as machine - also competed for attention. However, the dominant idea of the body throughout the early modern period was undoubtedly the age-old one - that of a seething sack of fluids prone to overfilling. ${ }^{46}$

In the sixteenth and seventeenth centuries, astrology and astronomy had a strong presence in medical theory (both Galenic and Paracelsian) and popularised versions of these ideas were disseminated to broad and heterogeneous audiences through the millions of almanacs that poured off the presses. In the 1660s one in three families bought an almanac yearly. ${ }^{47}$ Many of these contain an image of a 'zodiacal man' which illustrated how each part of the body was governed by an astrological sign. ${ }^{48}$ The four humours of the body were influenced by the planets and the signs of the zodiac and restoring the body to humoral equilibrium inevitably required some knowledge of the state of the heavens at different times of the year. Moon-lore and knowledge of eclipses were particularly important. A purge or phlebotomy administered at the wrong time could produce a negative outcome so almanacs supplied simple advice on the best

\footnotetext{
${ }^{45}$ Lindemann, Medicine and Society, p. 14.

${ }^{46}$ Lindemann, Medicine and Society, pp. 16, 19.

${ }^{47}$ Bernard Capp, Astrology and the Popular Press: English Almanacs 1500-1800 (London and Boston: Faber and Faber, 1979), p. 23. See also Louise Hill Curth, English Almanacs, Astrology and Popular Medicine, 1550-1700 (Manchester: Manchester University Press, 2007).

${ }^{48}$ Capp, Astrology, pp. 204-5; Lindemann, Medicine and Society, pp. 28-9.
} 
times to be bleed or receive a purge or emetic: 'Now art thou bid by gentle May/ Purge, vomit, bath and bleed'. ${ }^{49}$ Additionally, they carried prognostications about the weather for the coming year, prevalent diseases, and disastrous events like plagues, earthquakes, the deaths of highranking persons and civil unrest. Plagues could be caused by God's 'instruments'- the stars operating through divine permission. Almanacs also contained medical notes and advertised proprietary remedies such as 'Bateman's famous spirit of scurvy grass', as well as data on gardening and farming. ${ }^{50}$ Astrological medicine was not considered marginal or confined to back alleys; many prominent members of the College of Physicians were practising astrologers and it was particularly fashionable in European court circles. ${ }^{51}$

Just as individuals like Pepys and Josselin employed several different forms of medical help simultaneously or sequentially, so there appears to have been relatively little cognitive discomfort about the close association between supernatural/ religious and naturalistic medical explanations and cures. While ancient Hippocratic medicine had largely excluded the supernatural from its theories of the origins of disease, from the inception of Christianity, religion demanded a key role in medical explanations. ${ }^{52}$ Divine displeasure on account of collective human sin was thus the prime explanation for plague visitations; however, secondary causes - the mechanisms whereby God's punishment reached its victims - could be both supernatural and naturalistic. Evil angels, the stars, miasmic air and contagion were the favoured delivery agents listed in the vast number of plague pamphlets that poured off the presses during epidemics. ${ }^{53}$ In 1603-4 alone, twenty-eight books on plague were printed, circulating such beliefs. ${ }^{54}$ The physician and playwright Thomas Lodge railed in his treatise:

This sicknesse of the Plague is commonly engendered of an infection of the aire, altered with a venomous vapour...this dangerous and deadly infirmitie is produced and planted in us, which Almightie God as the rodde of his rigor and justice and for the amendment of our sinnes sendeth downe upon us (sig. B2v). ${ }^{55}$

\footnotetext{
${ }^{49}$ Capp, Astrology, p. 35; Wear, Knowledge and Practice, p. 381.

${ }^{50}$ Capp, Astrology, p. 205.

${ }^{51}$ Lindemann, Medicine and Society, pp. 251-2.

${ }^{52}$ Healy, Fictions of Disease, p. 19.

${ }^{53}$ Healy, Fictions of Disease, pp. 23-69.

${ }^{54}$ Paul Slack, The Impact of Plague in Tudor and Stuart England (1985; Oxford: Clarendon Press, 1990), pp. 23-4.

${ }^{55}$ Thomas Lodge, $A$ Treatise of the Plague (London, 1603). All citations are to this edition.
} 
Lodge foregrounded 'contagion' - 'an evil qualitie in a bodie, communicated unto an other by touch' (sig. B2v) - as an important mechanism for plague transmission and advocated fleeing from 'the conversation of those that are infected' (sig. L3r); indeed, most treatises urged readers to call upon God for help and then to get as far away as they could from the infected place.

God sent disease, but he played a key role in healing too. A remedy for fever taken from a manuscript written in Latin by the highly educated medieval nun trained in humoral medicine, Hildegard of Bingen, is illuminating of the important role of incantation in holy healing:

But when the person has a fever, take the fruit of the beech when it first ripens and mix it together in pure water, that is in spring water, and say these words: 'Through the holy girdle of the holy incarnation by which God became man, grow weak, you fever and you feverish conditions, and weaken your coldness and heat in this person N.; and then give this water to the person to drink; you shall provide it for five days, and if the person has a quotidian or quartan fever, he will be delivered from them quickly, or God does not wish to free him. ${ }^{56}$

It is likely that early modern 'white witches' regularly used such methods in which superstition overlapped with religion, and it is easy to understand how they could be accused by their detractors of darker practices. Other forms of religious healing included the use of relics, exorcism, the laying on of hands, supplications to saints, and blessings.

Judging by the popularity throughout the medieval and early modern periods of a book enticingly called The Book of Secrets of Albertus Magnus, magical cures were very commonly employed. The first English edition was published in 1550 and from then until 1637 it went through nine editions. ${ }^{57}$ Writing on books of secrets in this period, Louis B. Wright concluded that these texts were eagerly consumed by middle-class readers who were hungry for information about pseudo-science. ${ }^{58}$ They often suggest that their information comes from reputable sources like Aristotle and Pliny or, as in this case, Albertus Magnus. Magnus's Secrets reads as an anthology of superstitious lore, explaining the 'virtues' or marvellous properties of beasts, stones

\footnotetext{
${ }^{56}$ Jacques-Paul Migne, Patrologia Latina, tom. 197, S. Hildegardis abbatissae Opera Omnia (1855; Paris: Migne 1882), p. 197: 1235C; translated and cited in Debra L. Stoudt, 'Medieval German Women and the Power of Healing', in Lilian R. Furst (ed.), Women Healers and Physicians: Climbing a Long Hill (Kentucky: The University Press of Kentucky, 1997), pp. 13-42, 23-4.

${ }^{57}$ The Book of Secrets of Albertus Magnus: of the Virtues of Herbs, Stones and Certain Beasts, eds Michael R. Best and Frank H. Brightman (Oxford: Clarendon Press, 1973), Introduction, xii. All citations are to this edition.

${ }^{58}$ Louis B. Wright, Middle-Class Culture in Elizabethan England (Cornell: Cornell University Press, 1935), p. 562.
} 
and herbs. The address is engagingly personal and practical; for example: 'If thou wilt overcome beasts, and interpret or expound all dreams and prophesy of things to come. Take the stone which is called Amandinus. It is of divers colours...' (32). The following intriguing description is of a particularly efficacious herb, Verbena or Vervain:

The seventh is the herb of the planet Venus, and is called Peristerion, of some Hierobotane, id est Herba columbaria, and Verbena, Vervain. The root of this herb put upon the neck healeth the swine pox, impostumes behind the ears, and botches of the neck, and such as can not keep their water. It healeth also cuts, and swelling of the tewel, or fundament, proceeding of an inflammation which growth in the fundament; and the haemorrhoids. If the juice of it be drunken with honey and water sodden, it dissolveth those things which are in the lungs or lights. And it maketh a good breath, for it saveth an keepeth the lungs and the lights. It is also of great strengthin venereal pastimes, that is, the act of generation. If any man put it in his house or vineyard, or in the ground, he shall have abundantly revenues, or yearly profits; moreover the root of it is good to all them will plant vineyards or trees. And infants bearing it shall be very apt to learn, and loving learning, and they shall be glad and joyous. It is also profitable, being put in purgations, and it putteth aback devils.

Yet this is to be marked, that these herbs be gathered from the twenty-third day of the moon until the thirtieth day, beginning the gathering of them from the sign Mercurius, by the space of a whole hour, and in gathering make mention of the passion or grief, and the name of the thing for the which thou dost gather it. (22-4)

As well as curing incontinence and a spectrum of infections, Verbena heals cuts and haemorrhoids, lung diseases, solves bad breath, and improves sexual potency and conception rates. Additionally, it can make you rich and your children happy and more apt to learn. It is useful as a laxative ('in purgations'); and in the same manner that it helps to expel faeces it can eject devils. However, the herb must be gathered with an eye to moon-lore and under the astrological sign, Mercury, within an hour, during which time you must talk aloud, naming the reason why you are gathering the herb. Ritual and performance are thus crucial to maximising Verbena's 'virtues'.

To modern readers, this may seem like nothing more than laughable 'hocus pocus', akin to the homely, ludicrous 'old-wives' remedies advocated by the middle-class citizen's wife in Beaumont and Fletcher's, The Knight of the Burning Pestle: 
Faith and those chilblains are a foul trouble; mistress Merriethought, when your youth comes home, let him rub all the soles of his feet, and the heels, with a mouse skin, or if none of your people can catch a mouse, when he goes to bed, let him roll his feet in the warm embers, and I warrant you he shall be well, and you make him put his fingers between his toes and smell to them, it's very sovereign for his head if he be costive. ${ }^{59}$

This is certainly humorous; however, we should not underestimate the value of taking action and doing something, and of placebo effects, at a time when there were no true medical 'cures'. Magnus's Secrets alerts us to another widespread practice known as sympathetic magic in which herbs, minerals and animals that resembled - in terms of shape, colour, texture - something about the affliction, were thought to have curative virtues. For example, 'the stone which is called Chalzia' and 'hath the figure of hail and the colour and hardness of the Diamond', would, on account of its coldness (resembling hail), cool the heat of anger and lust (44-5). In a similar way, red plants would be used to treat bloody discharges and spotted and scaly plants to cure skin infections, while maidenhair tackled baldness. ${ }^{60}$ Amulets worn on the body were imagined to harness sympathetic powers to enhance health or counter disease. There was also a notion of transference: if you rubbed a cut onion on a wart and then left the onion to rot, the wart would shrivel along with the onion. ${ }^{61}$

By the 1640s books of magical secrets were clearly losing a certain currency (the last English edition was published in 1637) and texts such as Gerard's Herbal (1597) were gaining ground. It is informative to compare Gerard's description 'Of Vervaine' to the one above. Gerard's Herbal supplies a detailed, technical description of the plant with an accurate picture. It tells the reader where to find it, the month it flowers, its Latin and English names, and proceeds to 'the Vertues':

\section{Of Vervaine:}

It is reported to be a singular force against the Tertian and Quartaine fevers: but you must observe mother Bombies rules, to take just as many knots or sprigs, and no more, lest it fall out so that it do you no good, if you catch no harme by it. Many odde old wives fables are written of Vervaine tending to witchcraft and sorcery, which you may

\footnotetext{
${ }^{59}$ Beaumont and Fletcher, The Dramatic Works of Beaumont and Fletcher, ed. Fredson Bowers (Cambridge: Cambridge University Press, 1966), Act 3, Scene 3., 11. 188-95.

${ }^{60}$ Lindemann, Medicine and Society, p. 26.

${ }^{61}$ Lindemann, Medicine and Society, p. 26.
} 
reade elsewhere, for I am not willing to trouble your eares with reporting such trifles, as honest eares abhorre to heare.

Most of the later Physitions do give the juice or decoction hereof to them that have the plague: but these men are deceived...they looke for some truth from the father of falsehood ... for it is reported, that the divill did reveale it as a secret and divine medicine. $^{62}$

This text is clearly determined to separate itself from superstitious herbals such as books of secrets 'tending to witchcraft and sorcery' and peddling 'odde old wives fables'; the sort of thing 'honest eares abhorre'. However, it advocates 'mother Bombie's rules'; that is, cunning-woman's lore about gathering Vervaine, and it takes a curious swipe at 'Physitions' who use the herb to treat plague. It suggests that such physicians have taken the devil's advice-they are practising Satanic physic which they have sought from 'the father of falsehood': by implication, they are in league with the devil. In Gerard's Herbal religious belief has replaced magical lore and even as it presents itself as more objective and quasi-scientific, it confirms its belief in a supernatural environment troubled by the foul workings of the devil.

To conclude, then, in early modern Europe, medical care began in the home and neighbourhood and the majority of healers were thus women. From time-to-time families sought the services of a variety of mostly unlicensed practitioners ranging from herbalists and cunning women to quacks and mountebanks; professional physicians were not the popular choice even in well-to-do households. There was a broad stratum of shared cultural beliefs about health, illness, and cures, which incorporated both supernatural and naturalistic ideas, and which traversed high and low, learned and lay social domains; this was popular medicine.

${ }^{62}$ John Gerard, Gerard's Herbal: the history of plants, ed. Marcus Woodward (London: Senate, Studio Editions Ltd, 1994), pp. 161-2. 